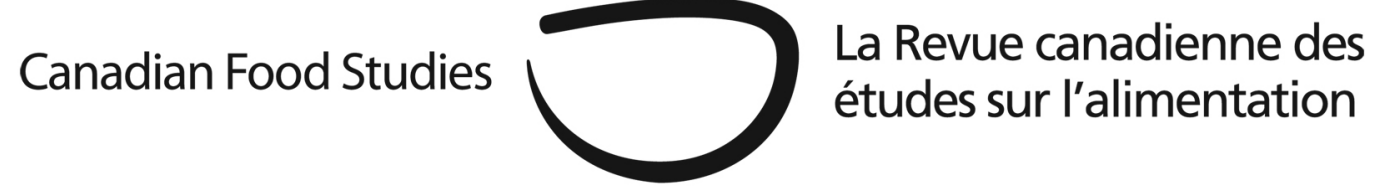

Section VII

Land grabs and agrarian reform

Special Issue: Mapping the Global Food Landscape

\title{
Fixing the land: The role of knowledge in building new models for rural development
}

Wendy Wolford

Robert A. and Ruth E. Polson Professor, Department of Development Sociology, Cornell University

Over the past five years, the term "land grab" has made international headlines. First coined by activists documenting the rise in media reports about displacements caused by the sale or transfer of land (GRAIN, 2009), land grabbing quickly became an object of academic research and debate (Borras, Hall, Scoones, White, \& Wolford, 2011; Deininger et al., 2011). Although the phenomenon of land grabbing - both as a characteristic of the contemporary global conjuncture and as a specific set of practices in particular places - has been difficult to precisely define (Edelman, 2013; Oya, 2013; Scoones, Hall, Borras, White, \& Wolford, 2013), academics, activists, development practitioners, and policy-makers largely agree that there has been a concerted and increased rush to acquire land over the past decade (Anseeuw, Lay, Messerli, Giger, \& Taylor, 2012, 2013; Li, 2014; Pearce, 2012). Conservative estimates suggest that largescale land acquisitions (LSLA, as they are commonly known) have resulted in a ten- to twentyfold increase in the amount of land changing hands annually since 2008 (over the annual average of the preceding forty years) (Arezki, Deininger, \& Selod, 2011, p. 1). Ongoing research suggests that investments were prompted by a combination of factors, such as the so-called global food crisis of 2007-08; concerns over land and energy scarcity; elite politics at multiple levels' and market failures, particularly in housing and insurance, which liberated considerable capital for investment (Arezki, Deininger, \& Selod, 2011; McMichael, 2014). In this context, a wide range of investors have sought out land as a profitable or necessary investment, from nation-states and state-owned enterprises seeking reliable access to food and fuel to hedge-fund managers who are attracted to farmland as a profitable, long-term addition to their portfolio. 
Since 2009, considerable research has been done on LSLAs from a variety of disciplines. Notwithstanding the definitional challenges, important work has been done in an effort to quantify land deals (Anseeuw, 2012, 2013) and extrapolate the consequences of such large-scale land transfers for food security (Cotula, 2009; Rulli \& d'Odorico, 2014) and the environment (Rulli \& d’Odorico, 2014). Qualitative research has been conducted on land deals around the world with attention to the classic questions of political economy, namely how surplus is extracted from the land and how it is distributed before and after exchange (Borras et al., 2011). This fine-grained empirical research has built on extensive knowledge of local conditions and political-economic contexts, both of which are essential to knowing how land deals work and for whom. Theoretical work has also examined the meaning of land deals for the larger political economy (and vice versa), both historically and spatially (McMichael, 2014). Scholars from various fields not working directly on land transfers have also used LSLAs as a window onto broader conditions, allowing them to examine the nature of the contemporary state (Wolford, Borras, Hall, Scoones \& White, 2013), the meaning and measure of land (Edelman, 2013), the role of nature in modern society (Fairhead, Leach, \& Scoones, 2012), and the specific dynamics of urban growth (Baka, 2013; Levien, 2013). In general, research suggests that land deals often take place in areas already under small-scale or subsistence production with the intent of producing commodities for export; investors often make promises about inclusion and community development, but find themselves unwilling or unable to follow through; fair, prior and informed consent is crucial but often lacking; and people often engage in labor and markets directly tied to the investment rather than having their opportunities expanded or improved more generally.

At the same time as research on LSLAs has increased, so has work on what might be considered the alternative: peasant movements, agro-ecological farming, and food sovereignty. While these are not always formulated or even mobilized in response to LSLAs, they operate under a different set of assumptions and in so doing, present an epistemological as well as ontological challenge to large-scale transfers and production schemes (Van der Ploeg, 2008). Coming together under the umbrella of La Vía Campesina, movements of small farmers, rural workers, landless squatters, and environmentalists are working to preserve and create alternatives that privilege small-scale, ecologically sustainable forms of production that support and expand the local capacity for social reproduction (Edelman et al., 2014; Wittman, Desmarais, \& Wiebe, 2010).

\section{Understanding knowledge production}

Although much has been written on global land deals, there is much more to be done. In particular, I argue that not enough attention has yet been paid to the ways in which different forms of knowledge are mobilized and circulated in defense of LSLAs or in support of alternatives. Without analyzing the production, circulation, and negotiation of knowledge—of 
assumptions, ideas, models, and paradigms — we cannot understand how LSLAs and the promotion of input-intensive agro-industrial commodity production came to be seen as the obvious solution to increased hunger in the wake of the 2007-08 World Food Crisis. ${ }^{1}$ In the sections that follow, I outline a possible agenda for exploring knowledge production in three key areas.

First, we need to know how different forms of knowledge, including scientific, legal, social, and political, are constructed, legitimated, and contested. This is particularly true in the area of agricultural extension and rural development, where models and plans for "improvement" or progress are predicated on very particular knowledge forms. Of particular interest is the way in which western science is mobilized to justify large-scale land deals. Agricultural sciences from agronomy to plant breeding are invoked to propose both the problems (the high yield gap, whereby local agricultural production does not meet the yields obtained in purportedly similar agroecological regions) and the solution (technologies deemed to utilize "universal scientific principles" that maximize production and efficiency). The validity of this knowledge often goes unquestioned, even when it is contested as inappropriate or extractivist, but science itself needs to be situated historically and spatially in order to understand both its particularity and the power dynamics behind its production and dissemination. How does such science come to be seen as necessary and superior to other ways of organizing agricultural production? How are scientific understandings influenced by critical differences in land use, environmental imaginaries, and local politics in different places? In my own research in Mozambique, plans to mimic Brazilian agricultural development have been enthusiastically supported by government, private industry, and development practitioners alike because all three groups believe that universal scientific principles will facilitate the transfer of knowledge from locations as different as Brazil and Mozambique (Wolford \& Nehring, 2015; Wolford, 2015).

Second, we need to know more about how experts and different forms of expertise are influencing access to land in rural areas of the world. The push for large-scale land deals as a means of resolving global food security or low levels of productivity in local and national agriculture rests more broadly on the relationship between land and development. In this respect, land deals are brokered by an increasingly vast field of development consultants, scientists, bureaucrats, and investors, all of whom wield forms of expertise that have considerable influence on the ground and in government halls. One piece of the new context is the role of so-called “emerging economies” (Brazil, Russia, India, China, and South Africa, or the BRICS) in what is called South-South development—wherein the expertise of experience combines with notions of similarity and solidarity to justify partnerships in development. Another piece of the context is the near-universal belief that protecting land rights by providing legal title is the key to regulating land deals and mitigating their most negative effects (Peters, 2013). Such claims for the need to title property derive credibility from the classic case of English development, but play out in different ways on the ground. Land titles can protect the right people have to resources, but titling can also be a way of dividing communities and commodifying a resource

\footnotetext{
${ }^{1}$ http://www.un.org/press/en/2009/gaef3242.doc.htm
} 
formerly held in common or through custom. Beyond title, attention needs to be paid to the multiple, overlapping and occasionally antagonistic way in which people gain access to the land in particular places (Ribot \& Peluso, 2003).

Third, and finally, we need to know more about the ways in which these new land deals and the knowledge forms accompanying them are actually re-shaping rural livelihoods and landscapes. For several years now, there have been calls to conduct research on the actual material and symbolic effects of land deals (Deininger et al., 2012; White, Borras, Hall, Scoones \& Wolford, 2012). Such research is difficult to accumulate for several reasons: first, many land deals are still in name only and the actual or expected effects are several years away from materializing; second, the effects play out differently for different groups and extensive research is required to capture the impressions and experiences of a variety of actors across scales; third, the effects are dynamic and need to be seen as not just changes that manifest from point $A$ to point $\mathrm{B}$, but rather as an ongoing set of negotiations, contestations, and concrete changes; and fourth, it is difficult to assess land deals against a specific alternative because the potential range of alternatives (what strategies could have been followed if not for the land deal) are difficult to identify.

In a sense, however, investigating the impacts of land deals requires unpacking the widespread faith in the capacity of markets to introduce and improve wellbeing. Perhaps the key difference between LSLAs and their alternatives is their relationship to the market. Here, the discipline of economics plays a critical role in shaping our understanding of market dynamics and effects; this form of knowledge, however, is only one way of understanding production and exchange, and assumptions built into economic models can be misleading. There are significant tensions in the official agendas for rural development between smallholder production, food security, and large-scale agro-industrial export production. Governments often "resolve" the tension between land concentration and distribution through increased commercialization, market access, and profitability. Small holders are being incorporated into large-scale schemes, largely as day laborers or through contract farming. This focus on economics and the market is in danger of generating greater differentiation in the countryside by privileging wealthier farmers, corporate interests, and large-scale commodity production rather than livelihood or food security concerns.

\section{Policy implications of LSLAs}

There have been several high profile, ongoing discussions about the policy and legal implications of land deals.

There is a clear need to support ongoing and further research on both LSLAs and their alternatives. There are organizations such as the Land Matrix and the Land Deals Politics Initiative currently acquiring information through database surveys and grounded empirical 
research respectively, but these efforts need to be expanded and supported. This work also needs to link more directly and clearly to policy makers and practitioners.

There is also much energy in the work that has been done (and is being done) at the international level to provide guidance on regulating land deals. The importance, visibility and power of civil society was clear in the immediate international response to LSLAs and to the reaction in the Food and Agriculture Organization of the United Nations (FAO). While the World Bank proposed its own guidelines for behaving responsibly in the face of LSLAs, social movements immediately reacted by organizing a counter-response both locally and internationally. It is not clear whether that response will have real staying power given the interests of institutional, state, and financial capital, but several policy directions come out of the organizing work being done.

The Voluntary Guidelines put forward by the FAO need public support by national governments that also require legal assistance to determine how to comply with the guidelines. For many states, complying with the guidelines will mean fundamentally re-thinking how public, private, and civil communities access and use land. Legal assistance will be key to instituting transparent, inclusive, and progressive rules about land access and use. Along those lines, there needs to be a continued discussion at multiple levels as to what constitutes sufficient protection of land rights and use (both formal and informal). This is about the nature of democracy, as local groups need to have adequate representation and voice in the face of external interests in land and natural resources.

One of the most important policy implications of the focus on knowledge, however, is the need to fund research and extension for agriculture and rural development that does not concentrate solely on yield but rather on sustainability, livelihood, and local economies. There needs to be critical support for national extension agencies and agents such that they are equipped to promote sustainable production methods and able to reach a significant percentage of their target population. Public extension agencies have suffered extensive cuts over the past decade, making private Research and Development seem like the only avenue to everything from improved varieties, or genetically modified organisms, to market access.

To that end, policies and programs should be designed with the intention of rebuilding public research and extension systems such that plant breeding and agronomy work with the private sector but are not dominated by it. Large-scale public plant breeding efforts need to be oriented towards sustainable production of local food and fiber crops (not simply commodity crops), including grains, tubers, and legumes.

\section{Some questions for future research}

Examining knowledge in relation to land deals presents a number of challenges because knowledge is simultaneously institutional and codified and individual and unspoken. The knowledge we need to understand is the "rules of the game", encompassing the institutions that 
shape land deals as well as the norms and ideals that come to be taken as common sense. Which future is likely to feed the hungry and the poor? Which future will become common sense, human nature and taken for granted? Will the demise of small farmers finally become reality and, if so, with what effect? These are loaded questions and there is so much at stake.

Contextualizing knowledge in relation to land will require the articulation of many different scientific fields that rarely come in to conversation. On the social science and humanities side, there will need to be attention to: science and technology studies and the sociology of knowledge, environmental history, geographies of development, and critical agrarian studies. On the biology and life sciences side, there will need to be attention to: plant breeding, soil sciences, and ecology. All of these will provide the tools to examine the following two questions: what forms of knowledge generate the need for LSLAs and how are they deployed throughout the process; and what alternate ways of knowing are available and how do these engage with dominant forms of knowledge and to what effect?

\section{References}

Anseeuw W., Lay, J., Messerli, P., Giger, M., \& Taylor, M. (2012). Transnational land deals for agriculture in the global South analytical report based on the land matrix Database. The Land Matrix Partnership. Retrieved from http://www.oxfam.de/sites/www.oxfam.de/files/20120427_report_land_matrix.pdf

Anseeuw W., Lay, J., Messerli, P., Giger, M., \& Taylor, M. (2013). Creating a public tool to assess and promote transparency in global land deals: The experience of the Land Matrix. Journal of Peasant Studies, 40(3), 521-530.

Arezki, R., Deininger, K., \& Selod, H. (2011). What drives the global land rush? (Working Paper 5864). Washington, D.C.: World Bank. Retrieved from http://elibrary.worldbank.org/doi/pdf/10.1596/1813-9450-5864

Baka, J. (2013). The political construction of wasteland: Governmentality, land acquisition and social inequality in South India. Development and Change, 44, 409-428.

Borras, S., Hall, R., Scoones, I., White, B., \& Wolford W. (2011). Towards a better understanding of global land grabbing: An editorial introduction. Journal of Peasant Studies, 38(2), 209-216. 
Cotula, L. (2009). Land grab or development opportunity? International Institute for the Environment and Development. Retrieved from http://www.ifad.org/pub/land/land_grab.pdf

Deininger, K. W., Byerlee, D., Lindsay, J., Norton, A., Selod, H., \& Stickler, M. (2011). Rising Global Interest in Farmland: Can it Yield Sustainable and Equitable Benefits? Washington, D.C.: World Bank.

Edelman, M., (2013). Messy hectares: Questions about the epistemology of land grabbing data. Journal of Peasant Studies, 40(3), 485-501.

Edelman, M., Weis, T., Baviskar, A., Borras Jr, S. M., Holt-Giménez, E., Kandiyoti, D., \& Wolford, W. (2014). Introduction: Critical perspectives on food sovereignty. Journal of Peasant Studies, 41(6), 911-931.

Fairhead, J., Leach, M., \& Scoones, I. (2012). Green grabbing: A new appropriation of nature? Journal of Peasant Studies, 39(2), 237-261.

GRAIN. (2009). The new farm owners. Retrieved from http://www.grain.org/article/entries/194the-new-farm-owners

Levien, M. (2013). Regimes of dispossession: From steel towns to special economic zones. Development and Change, 44(2), 381-407.

Li, T. (2014). What is land? Assembling a resource for global investment. Transactions of the Institute of British Geographers, 39(4), 589-602.

McMichael, P. (2014). Rethinking land grab ontology. Rural Sociology, 79(1), 34-55.

Oxfam. (2012). Our land, our lives: Time out on the global land grab. Oxfam International Briefing Notes. Retrieved from http://policy-practice.oxfam.org.uk/publications/our-landour-lives-time-out-on-the-global-land-rush-246731

Oya, C. (2013). Methodological reflections on 'land grab' databases and the 'land grab' literature 'rush'. Journal of Peasant Studies, 40(3). 503-520.

Pearce, F. (2012). The landgrabbers: The new fight over who owns the earth. Boston, MA: Beacon Press Books. 
Peters, P.E. (2013). Conflicts over land and threats to customary tenure in Africa. African Affairs. Retrieved from http://afraf.oxfordjournals.org/content/early/2013/08/07/afraf.adt047.abstract

Ribot, J.C., \& Peluso, N.L. (2003). A theory of access. Rural sociology, 68(2), 153-81.

Rulli, M. C., \& D’Odorico, P. (2014). Food appropriation through large scale land acquisitions. Environmental Research Letters, 9(6), 064030.

Scoones, I., Hall, R., Borras Jr, S. M.,White, B., \& Wolford, W. (2013). The politics of evidence: A response to Rulli and D'Odorico. Journal of Peasant Studies, 40(5), 911-912.

Van Der Ploeg, J. D. (2008). The New Peasantries: Struggles for Autonom and Sustainability in an Era of Empire and Globalization. London: Earthscan.

White, B., Borras Jr, S.M., Hall, R., Scoones, I., \& Wolford, W. (2012). The new enclosures: Critical perspectives on corporate land deals. Journal of Peasant Studies, 39(3-4), 619-647.

Wittman, H., A. Desmarais, A., \& Wiebe N. (eds.). (2010). Food sovereignty: Reconnecting food, nature and community. Fernwood Publishing and FoodFirst Books: Halifax and Oakland.

Wolford, W., Borras, S. M., Hall, R., Scoones, I., \& White, B. (2013). Governing global land deals: The role of the state in the rush for land. Development and Change, 44, 189-210.

Wolford, W., \& Nehring, R. (2015). Constructing parallels: Brazilian experts, expertise and the commodification of land, labor and capital in Mozambique, Canadian Journal of Development Studies/Revue canadienne d'études du développement, 36(2), 208-223.

Wolford, W. (2015). From Pangaea to partnership: The many fields of rural development. Sociology of Development, inaugural double issue 1(2). 